\title{
SISTEM INFORMASI VISITASI AKREDITASI PROGRAM STUDI TEKNIK INFORMATIKA
}

\author{
Rully Indra Laelaningrum ${ }^{1}$, Yulia Islamiati ${ }^{2}$, Parsumo Rahardjo $^{3}$, Mardiyono $^{4}$ \\ Jurusan Teknik Elektro, Politeknik Negeri Semarang \\ E-mail: ${ }^{1}$ rullyindraa@gmail.com, ${ }^{2}$ yuliaislamiati21@gmail.com, ${ }^{3}$ parsumo@yahoo.com, ${ }^{4}$ m4rdiyono@yahoo.com
}

\begin{abstract}
Abstrak
Permasalahan yang sering terjadi saat proses visitasi akreditasi adalah pencarian dokumen dalam bentuk hardcopy untuk ditunjukkan kepada asesor yang memerlukan waktu lama. Masalah selanjutnya adalah proses penilaian asesor internal yang belum terintegrasi dalam sebuah sistem informasi sehingga menyulitkan pengguna dalam memantau perkiraan hasil nilai secara langsung. Tujuan dari penelitian ini adalah membangun sistem informasi visitasi akreditasi program studi. Sistem ini menggunakan metode Waterfall yang tahapannya dilakukan secara berurutan dimulai dari tahap analisis, perancangan sistem, penulisan kode program, pengujian sistem dan pemeliharaan sistem. Sistem dibangun dengan bahasa pemrograman web PHP dan framework Laravel. Penerapan sistem dilakukan di Program Studi Teknik Informatika Politeknik Negeri Semarang. Pengujian dilakukan dengan metode black box yang menguji fungsi masing-masing fitur dan pengujian kepuasan pengguna menggunakan kuesioner. Hasil pengujian menunjukkan bahwa sistem informasi telah berhasil berjalan dengan baik pada 3 browser yang berbeda dengan tingkat kepuasan pengguna mencapai $83.27 \%$ dari 11 responden. Penerapan sistem informasi ini akan membuat proses penilaian dan pengecekan dokumen visitasi akreditasi program studi menjadi lebih baik.
\end{abstract}

Kata kunci : Akreditasi, Sistem Informasi, PHP, Laravel

\begin{abstract}
The problem that often occurs during the visitation of accreditation process is to search the documents in hardcopy to be shown to assessors that takes a time. The next problem is the process of assessing of internal assessors which have not been integrated in an information system that makes difficult for user to directly monitor the estimated value of the results. The objective of this research is to develop an information system for visitation of study programs accreditation. This system uses the Waterfall method that its stages are performed sequentially starting from the analysis, system design, coding, testing and maintenance. The system is developed utilizing web programming languages of PHP and Laravel framework. The application of the system is implemented in the Informatics Engineering Study Program of Politeknik Negeri Semarang. The testing is done with a black box method that tests the functions of each feature and tests user satisfaction using a questionnaire. The results show that the system has worked successfully in 3 different browsers with user satisfaction reaching $83.27 \%$ of 11 respondents. The implementation of this information system will make the assessment process and checking visitation documents for study program accreditation better.
\end{abstract}

Keywords: Accreditation, Information Systems, PHP, Laravel

\section{Pendahuluan}

Pada proses visitasi akreditasi program studi, permasalahan yang sering kali muncul adalah pencarian dokumen dalam bentuk hardcopy untuk ditunjukkan kepada asesor. Petugas harus mencari dokumen pada tumpukan berkas sehingga membutuhkan waktu yang cukup lama. Permasalahan yang selanjutnya adalah proses penilaian asesor internal terhadap borang program studi dilakukan secara terpisah. Hal ini tidak memungkinkan program studi untuk melihat dengan cepat rekapitulasi nilai yang sudah diisi oleh asesor internal.
Beberapa peneliti telah melakukan pendekatan terkait permasalahan dalam administrasi dan dokumentasi proses akreditasi menggunakan sistem informasi. Selain diterapkan pada akreditasi perguruan tinggi, sistem informasi akreditasi juga telah diterapkan pada pendidikan PAUD[1] dan sekolah[2]. Kedua sistem informasi ini masih terbatas pada penilaian dan proses borang akreditasi yang diajukan. Pada perguruan tinggi, beberapa sistem informasi akreditasi telah diterapkan seperti Sistem Informasi Akreditasi Prodi (SIAKAP) Berbasis e-Arsip[3], sistem informasi BAN-PT[4], sistem penyusunan borang program studi (Buku IIIA)[5][6], penerapan aplikasi dashboard untuk persiapan akreditasi[7], penerapan sistem 
informasi kemahasiswaan guna menunjang akreditasi Prodi[8], penerapan sistem informasi kegiatan akademik untuk akreditasi[9], dan penerapan desain sistem evaluasi diri program studi [10]. Keseluruhan sistem informasi yang dibangun telah mampu menyediakan informasi data-data pendukung akreditasi serta evaluasi diri namun masih terdapat kekurangan berupa belum terintegrasi dengan penilaian asesor internal untuk memprediksi nilai borang dan data standar borang yang tidak dinamis.

Makalah ini membahas pembangunan Sistem Informasi Visitasi Akreditasi Program Studi Teknik Informatika yang bernama SIVA TI. Sistem ini selain menyediakan fitur - fitur yang sudah ada meliputi pengisian, pengunggahan file bukti akreditasi, juga terdapat form penilaian asesor internal untuk melakukan skoring sebelum dinilai oleh asesor dari BAN-PT, serta review nilai borang yang dapat menjadi bahan evaluasi program studi dalam menyiapkan akreditasi.

\section{Metode}

Dalam pembuatan Sistem Informasi Visitasi Akreditasi Program Studi, metode penelitian yang digunakan adalah metode Waterfall, meliputi analisis, desain, penulisan kode program, pengujian dan pemeliharaan. Pada bagian ini akan dibahas lebih jelas mengenai gambaran umum sistem, perancangan sistem, perancangan antarmuka, penulisan kode program, dan pengujian.

\subsection{Gambaran Umum Sistem}

Terdapat 4 (empat) pengguna pada sistem ini yaitu Admin, Penilai Internal, Kaprodi (Ketua Program Studi), dan Asesor. Pengelolaan data meliputi menambah, mengubah, maupun menghapus data pada sistem. Admin mempunyai hak akses mengelola data standar, elemen, deskriptor, serta mengunggah file bukti dari masing - masing deskriptor. Penilai Internal hanya dapat melihat file bukti serta memberikan penilaian pada hasil bukti di masing - masing deskriptor. Sedangkan kaprodi hanya bisa melihat file bukti dan nilai yang telah di berikan penilai internal pada masing - masing deskriptor. Untuk asesor hanya dapat melihat file bukti pada masing - masing deskriptor.
Data yang digunakan dalam sistem meliputi data yang diambil dari berbagai sumber, yaitu P3 (Pusat Pengembangan Pembelajaran), Perpustakaan, P3M (Pusat Pengembangan dan Pengabdian Masyarakat), UPT Bahasa, BAAK, LSP (Lembaga Sertifikasi Profesi), dan PPMP (Pusat Penjaminan Mutu Politeknik).

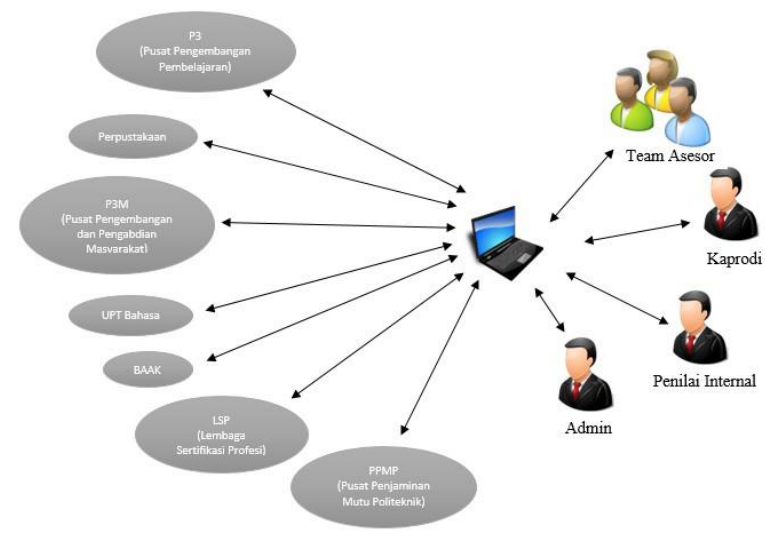

Gambar 1. Gambaran Umum Sistem

\subsection{Perancangan Sistem}

Perancangan sistem yang digunakan yaitu menggunakan UML atau Unifed Modelling Language sebagai media untuk menyampaikan rancangan sistem tersebut. Desain UML yang digunakan adalah Use Case Diagram dan Activity Diagram. Use Case Diagram dan Activity Diagram dapat dilihat pada Gambar 2 dan Gambar 3.

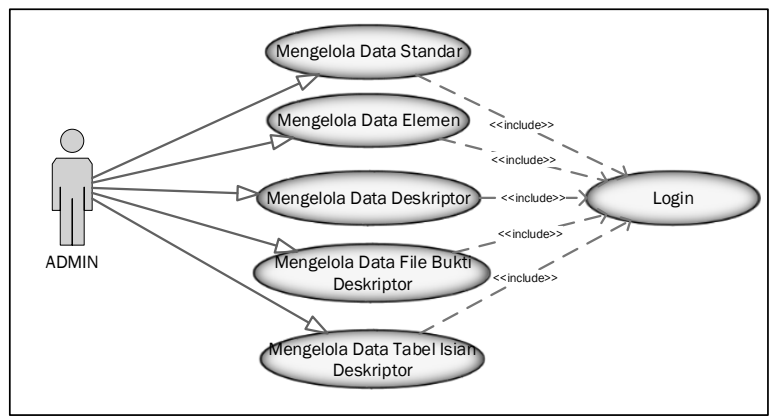

Gambar 2 Use Case Diagram 


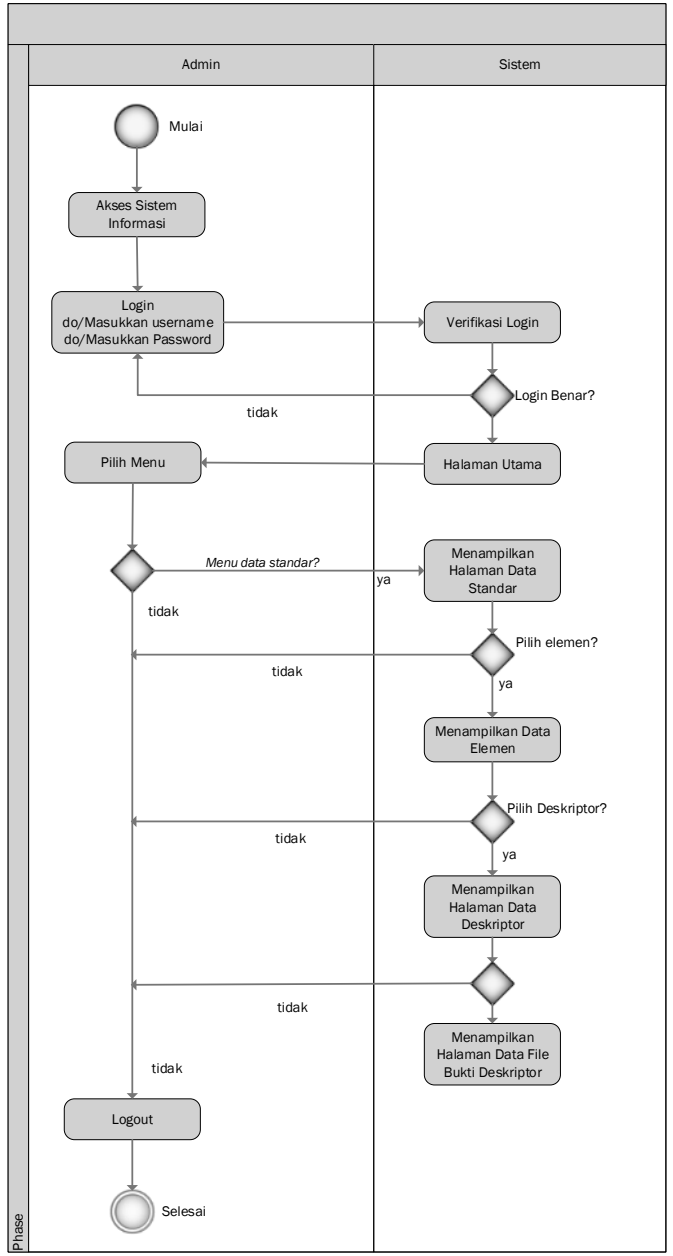

Gambar 3. Activity Digram

\subsection{Perancangan Antarmuka}

Perancangan antarmuka berguna untuk membuat gambaran tampilan sistem yang akan dilihat oleh pengguna.

\subsubsection{Halaman Login}

Halaman login merupakan halaman yang digunakan pengguna untuk masuk ke sistem agar dapat mengakses sistem sesuai posisinya. Pengguna harus mengisikan username dan password agar dapat mengakses sistem. Tampilan halaman login dapat dilihat pada Gambar 4.

Pada gambar 4 bagian 1 menunjukkan menu yang tampil pada halaman login yaitu menu SIVA TI untuk menuju ke halaman index, menu Standar untuk menuju halaman standar untuk asesor, dan register. Bagian 2 menunjukkan form yang berisi kolom username dan password yang diinput sesuai user yang sudah terdaftar.

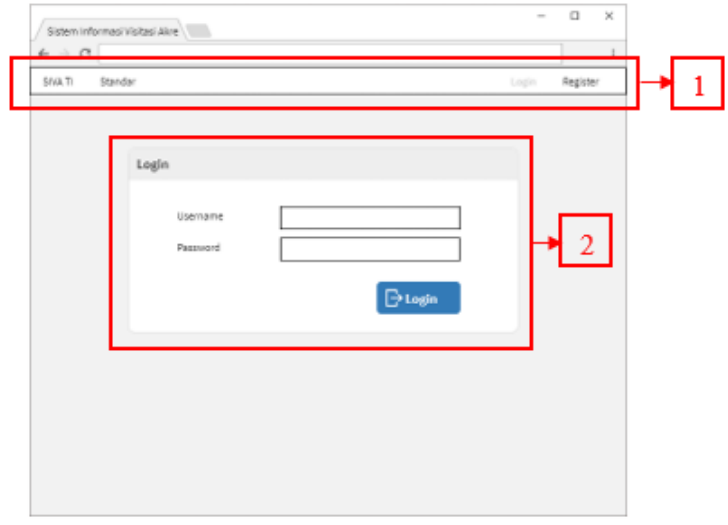

Gambar 4. Rancangan Halaman Login

\subsubsection{Halaman Admin}

Pada halaman admin ditampilkan beberapa menu pilihan yang dapat diakses oleh admin yaitu standar. Berikut tampilan halaman admin dengan menu standar dapat dilihat pada Gambar 5

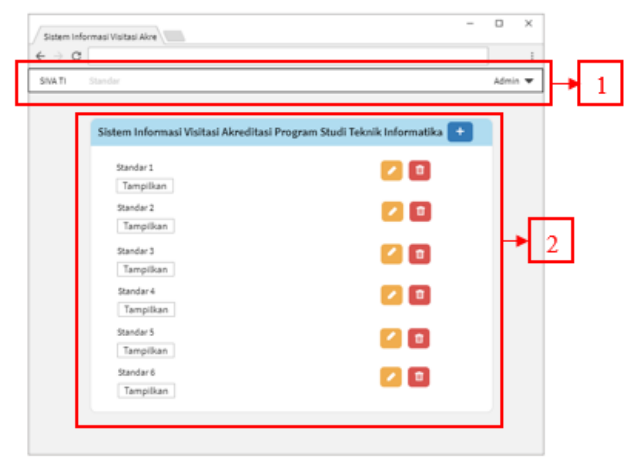

Gambar 5. Halaman Menu Standar Admin

Pada gambar tersebut, bagian 1 menjelaskan menu yang bisa diakses oleh admin, yaitu menu standar untuk membuka data-data standar. Bagian 2 menjelaskan bawa dalam halaman menu standar admin berisi tentang keterangan data standar yang juga terdapat beberapa tombol yang memungkinkan admin melakukan perintah CRUD data standar. Jika tombol "tampilkan" ditekan, maka akan muncul data-data elemen dalam setiap standar tersebut.

\subsubsection{Halaman Kaprodi}

Pada halaman kaprodi akan ditampilkan beberapa menu pilihan yang dapat diakses oleh kaprodi meliputi standar dan nilai. Berikut tampilan halaman kaprodi dengan menu standar dapat dilihat pada Gambar 6. 


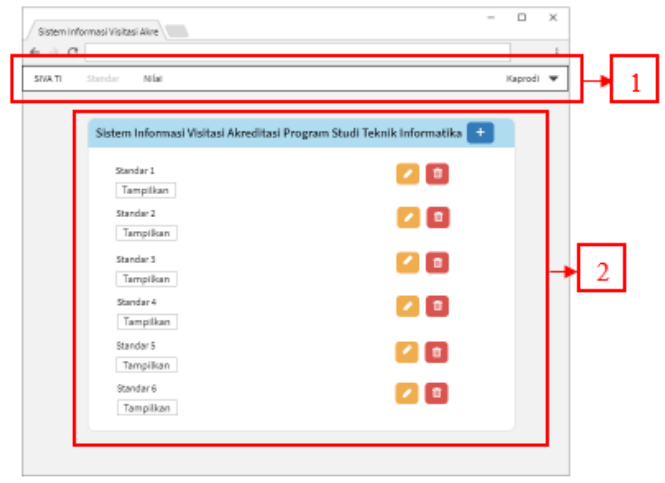

Gambar 6. Tampilan Halaman Menu Standar Kaprodi

Pada gambar tersebut, bagian 1 menjelaskan menu yang bisa diakses oleh kaprodi, yaitu menu standar untuk membuka data-data standar dan menu nilai untuk mengakses rekap nilai prediksi dari penilai internal. Bagian 2 menjelaskan bahwa dalam halaman menu standar kaprodi berisi tentang keterangan data standar dan terdapat beberapa tombol yang memungkinkan kaprodi melakukan perintah CRUD data standar. Jika tombol "tampilkan" ditekan, maka akan muncul data-data elemen dalam setiap standar tersebut.

\subsubsection{Halaman Penilai Internal}

Pada halaman penilai internal akan ditampilkan beberapa menu pilihan yang dapat diakses oleh penilai internal meliputi standar dan nilai. Berikut halaman penilai internal dapat dilihat pada Gambar 7.

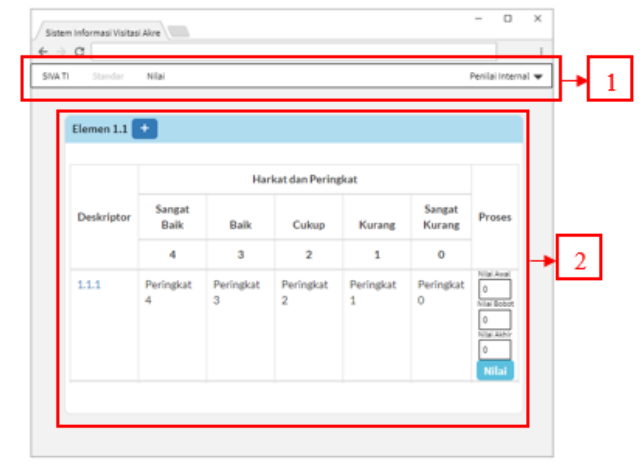

Gambar 7. Tampilan Halaman Deskriptor Penilai Internal

Pada gambar tersebut, bagian 1 menjelaskan menu yang bisa diakses oleh penilai internal, yaitu menu standar untuk membuka data-data standar dan menu nilai untuk mengakses rekap nilai prediksi dari penilai internal. Bagian 2 menjelaskan bahwa dalam halaman deskriptor penilai internal, berisi tentang keterangan deskriptor dalam setiap elemen. Pada halaman tersebut terdapat text field dan tombol "nilai" untuk mengisi nilai prediksi yang sudah diperoleh setiap deskriptor. Dan juga terdapat keterangan harkat dan peringkat yang harus didapat dalam setiap deskriptor sebagai acuan untuk mendapatkan nilai yang maksimal. Keterangan deskriptor penilaian tersebut berbentuk link yang menuju ke halaman selanjutnya, yaitu halaman file bukti deskriptor.

\subsubsection{Halaman Asesor}

Halaman ini merupakan halaman yang dapat diakses oleh user tanpa harus melalui login. Tampilan halaman yang ditujukan oleh assesor dapat dilihat pada gambar 8 .

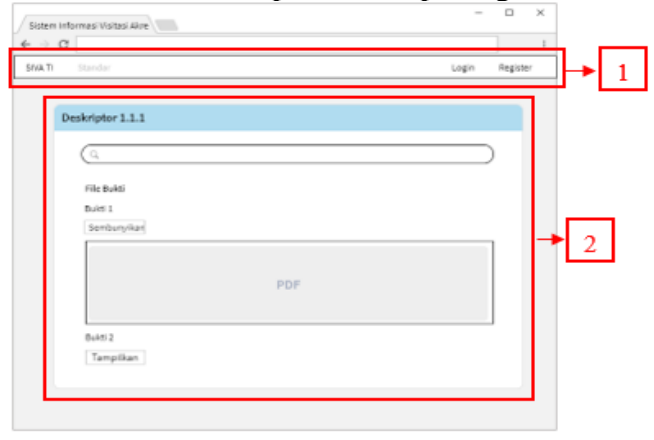

Gambar 8. Tampilan Halaman File Bukti Assesor

Pada gambar tersebut, bagian 1 menjelaskan menu yang bisa diakses oleh pengunjung umum atau asesor, yaitu menu standar untuk membuka data-data standar. Bagian 2 menjelaskan bahwa dalam halaman file bukti assesor, berisi tentang file bukti yang dimiliki oleh setiap deskriptor. Pada halaman tersebut terdapat kolom pencarian untuk mencari judul file bukti yang diinginkan. Dalam setiap file bukti terdapat tombol untuk menampilkan file dalam bentuk pdf pada sebuah frame yang

bisa diunduh jika dibutuhkan. Kemudian jika ingin ditutup, dapat dilakukan dengan menekan tombol sembunyikan.

\subsection{Penulisan Kode Program}

Penulisan kode program merupakan tahap implementasi dari perancangan sistem. Penulisan kode program pada sistem informasi akreditasi program studi teknik informatika dengan menggunakan framework Laravel.

\subsection{Pengujian}

Pengujian sistem adalah proses untuk memastikan keberhasilan sistem yang dibuat. Pengujian Sistem Informasi Visitasi Akreditasi Program Studi Teknik Informatika dilakukan dengan dua cara yaitu pengujian secara fungsional dan pengujian tingkat kepuasaan pengguna menggunakan kuisioner.

\section{Hasil dan Analisis \\ 3.1. Hasil Pengujian Fungsional}

Berdasarkan pengujian fungsionalitas sistem yang telah dilakukan, diperoleh hasil yang ditampilkan pada Tabel 1 . 
Tabel 1. Pengujian Fungsional Sistem Informas

\begin{tabular}{|c|c|c|c|c|}
\hline No & Pengujian & Microsoft & Mozilla & Google \\
\hline 1. & Tampilan pada Web Browser & $\sqrt{5}$ & $\sqrt{ }$ & $\sqrt{ }$ \\
\hline 2. & Login sistem & $\sqrt{ }$ & $\sqrt{ }$ & $\sqrt{ }$ \\
\hline 3. & $\begin{array}{l}\text { Pengoperasian } \\
\text { sebagai admin }\end{array}$ & $\sqrt{ }$ & $\sqrt{ }$ & $\sqrt{ }$ \\
\hline 4. & $\begin{array}{l}\text { Pengoperasian } \\
\text { sebagai kaprodi }\end{array}$ & $\sqrt{ }$ & $\sqrt{ }$ & $\sqrt{ }$ \\
\hline 5. & $\begin{array}{l}\text { Pengoperasian sistem } \\
\text { sebagai penilai internal }\end{array}$ & $\sqrt{ }$ & $\sqrt{ }$ & $\sqrt{ }$ \\
\hline 6. & Pengoperasian simpan data & $\sqrt{ }$ & $\sqrt{ }$ & $\sqrt{ }$ \\
\hline 7. & Pengoperasian edit data & $\sqrt{ }$ & $\sqrt{ }$ & $\sqrt{ }$ \\
\hline 8. & Pengoperasian hapus data & $\sqrt{ }$ & $\sqrt{ }$ & $\sqrt{ }$ \\
\hline 9. & Pengoperasian tampil data & $\sqrt{ }$ & $\sqrt{ }$ & $\sqrt{ }$ \\
\hline 10. & $\begin{array}{l}\text { Pengoperasian unggah file } \\
\text { deskriptor }\end{array}$ & $\sqrt{ }$ & $\sqrt{ }$ & $\sqrt{ }$ \\
\hline 11. & Logout sistem & $\sqrt{ }$ & $\sqrt{ }$ & $\sqrt{ }$ \\
\hline
\end{tabular}

Berdasarkan Tabel 1, dapat diambil kesimpulan bahwa semua aspek fungsional sistem informasi visitasi akreditasi program studi teknik informatika telah berfungsi dengan baik dan sesuai dengan perancangan sistem.

\subsection{Implementasi Sistem}

Implementasi sistem merupakan tahap penerapan perancangan yang telah dilakukan.

\subsubsection{Halaman Login}

Halaman login merupakan menu yang digunakan ketika pengguna ingin masuk kedalam menu sesuai dengan hak akses masing - masing. Pengujian fungsional pada proses ini dapat dilihat dari Gambar 9

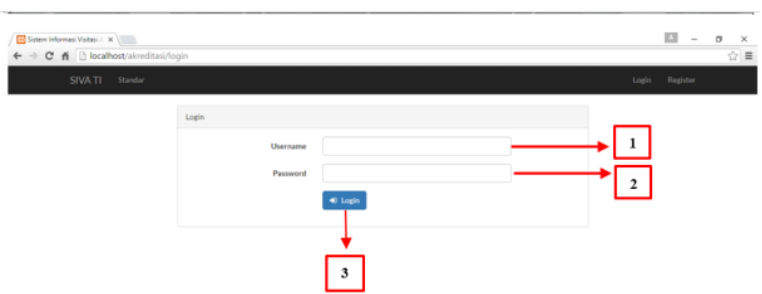

\section{Gambar 9. Tampilan Halaman login}

Gambar 9 adalah tampilan halaman menu login yang akan muncul ketika pengguna memilih menu login yang ada pada halaman utama. Bagian 1 adalah form username kemudian bagian 2 adalah form password berisi form untuk memasukkan username dan password serta bagian 3 yaitu tombol Login yang berfungsi untuk masuk ke dalam menu sistem sesuai hak akses masing - masing pengguna apabila username serta password benar. Proses masuk dari halaman login sudah berjalan dengan baik.

\subsubsection{Halaman Admin}

Halaman utama admin berisi menu yang ditampilkan saat login sebagai admin sesuai dengan hak akses yang dimiliki.
Pengujian fungsional pada proses ini dapat dilihat pada Gambar 10.

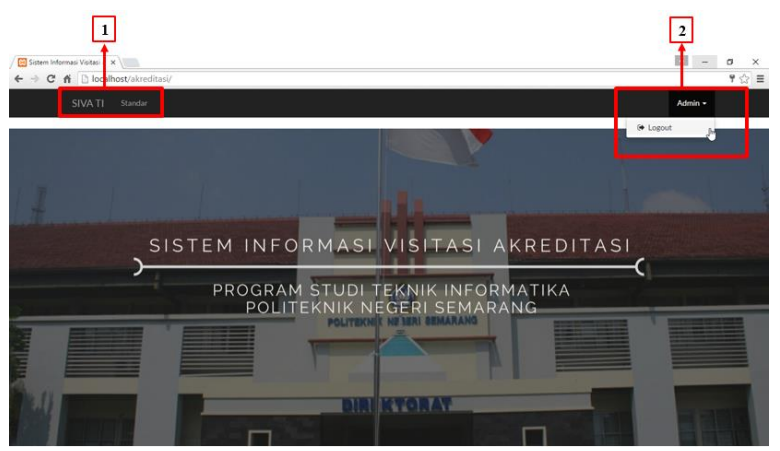

Gambar 10. Halaman Admin

Gambar 10 merupakan tampilan pada halaman admin. Pada bagian 1 terdapat menu standar yang dapat diakses oleh admin. Bagian 2 adalah menu dropdown pada username Admin untuk logout. Proses masuk dari halaman register sudah berjalan dengan baik.

\subsubsection{Halaman Kaprodi}

Halaman utama kaprodi berisi menu yang ditampilkan saat login sebagai admin sesuai dengan hak akses yang dimiliki. Pengujian fungsional pada proses ini dapat dilihat pada Gambar 11

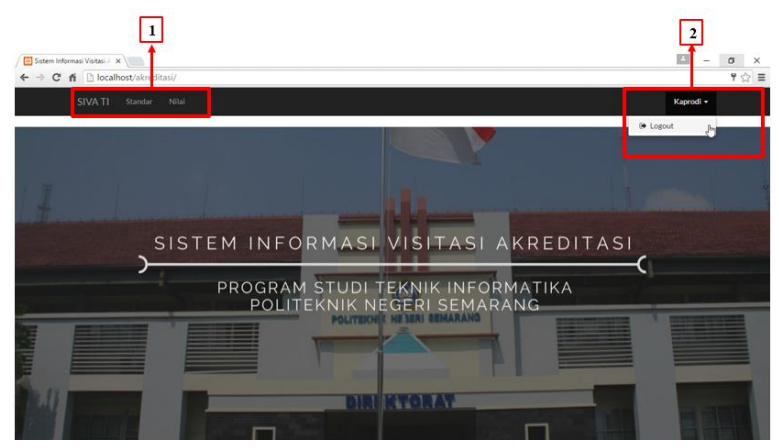

Gambar 11. Halaman Kaprodi

Gambar 11 merupakan tampilan pada halaman Kaprodi. Pada bagian 1 terdapat menu Standar dan Nilai yang dapat diakses oleh Kaprodi. Bagian 2 adalah menu dropdown pada username Penilai Internal untuk logout. Proses masuk dari halaman register sudah berjalan dengan baik.

\subsubsection{Halaman Penilai Internal}

Berikut halaman penilai internal pada bagian data deskriptor yang sesuai dengan elemen yang dipilih penilai internal. Pengujian fungsional pada proses ini dapat dilihat pada Gambar 12. 


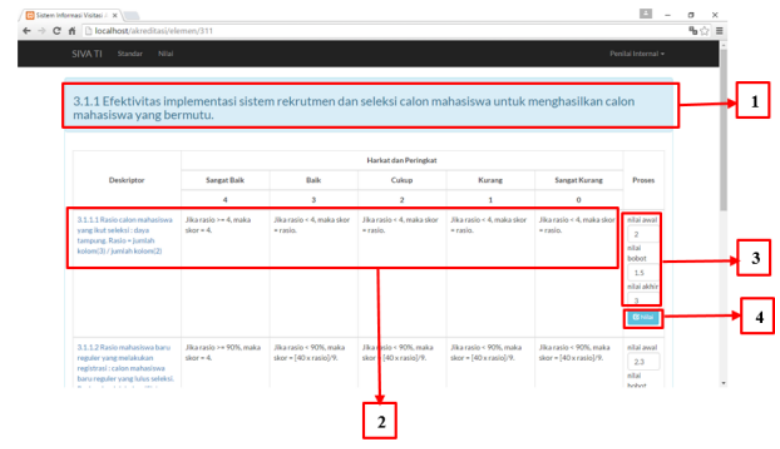

\section{Gambar 12 Halaman Penilai Internal}

Pada Gambar 12 menunjukkan halaman penilai internal yang menampilkan data deskriptor ditunjukkan pada bagian 2, dengan menggunakan judul elemen sesuai yang dipilih oleh penilai internal ditunjukkan pada bagian 1 . Penilai internal dapat mengisi nilai awal, nilai bobot yang dikalikan menghasilkan nilai akhir berdasarkan harkat dan peringkat yang diperoleh setelah melihat file bukti yang sudah dikumpulkan serta dapat mengubah kembali jika nilai awal dan nilai bobot yang sudah di masukkan yang ditunjukkan pada bagian 3 serta tombol nilai untuk menyimpan nilai yang dimasukkan oleh penilai internal.

\subsubsection{Halaman Asesor}

Berikut halaman asesor pada bagian file bukti deskriptor berisi tampilan file bukti dan tabel isian sesuai dengan deskriptor yang dipilih. Tampilan tersebut akan ditunjukkan pada Gambar 13.

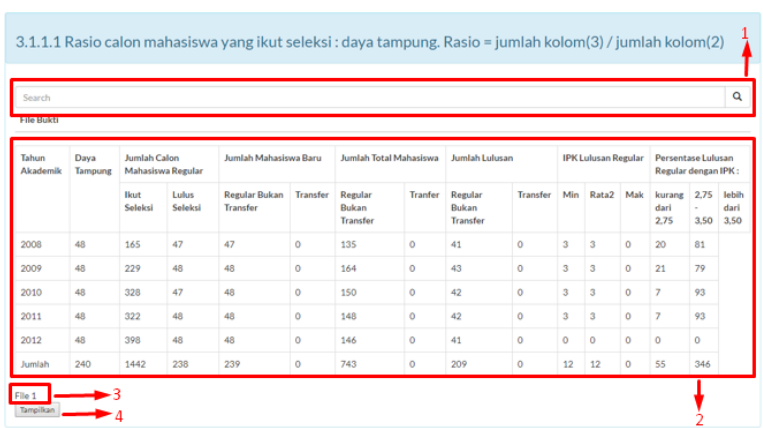

\section{Gambar 13. Halaman Asesor}

Gambar 13 merupakan tampilan dari file serta tabel isian yang dipilih oleh asesor yang telah diunggah dan dimasukkan oleh adminstrator atau kaprodi sebelumnya. Pada bagian 1 terdapat form cari yang digunakan untuk memudahkan pengguna dalam mencari data file bukti deskriptor. Kemudian bagian 2 adalah tampilan dari salah satu tabel yang telah diisikan oleh admin atau kaprodi. Bagian 3 adalah judul dari file bukti yang telah ditambahkan oleh admin atau kaprodi serta bagian 4 adalah tombol untuk menampilkan file bukti deskriptor.

\subsection{Hasil Pengujian Tingkat Kepuasan Pengguna}

Pengujian tingkat kepuasan pengguna merupakan tahap untuk mengukur tingkat kepuasan pengguna terhadap sistem informasi visitasi akreditasi program studi teknik informatika. Pengujian ini dilakukan oleh admin, kaprodi, penilai internal serta dosen yang terlibat dalam proses akreditasi program studi. Dalam proses pengujian, responden memberikan penilaian terhadap 5 pertanyaan yang ditunjukkan pada Tabel 2 .

\section{Tabel 2. Aspek Tingkat Kepuasan Pengguna}

\begin{tabular}{|c|c|}
\hline Kode & Pertanyaan \\
\hline \multirow{3}{*}{ A } & Apakah Anda setuju bahwa tampilan Sistem Informasi \\
\hline & $\begin{array}{l}\text { Visitasi Akreditasi Program Studi Teknik Informatika } \\
\text { menarik dan mudah diakses? }\end{array}$ \\
\hline & Apakah Anda setuju bahwa fitur yang diberikan pada \\
\hline \multirow[t]{2}{*}{$B$} & $\begin{array}{l}\text { Sistem Informasi Visitasi Akreditasi Program Studi } \\
\text { Teknik Informatika sudah lengkap? }\end{array}$ \\
\hline & Apakah Anda setuju bahwa Sistem Informasi Visitasi \\
\hline C & $\begin{array}{l}\text { Akreditasi Program Studi Teknik Informatika sudah } \\
\text { memenuhi kebutuhan pengguna? }\end{array}$ \\
\hline D & $\begin{array}{l}\text { Apakah Anda setuju bahwa waktu respon yang } \\
\text { diberikan Sistem Informasi Visitasi Akreditasi Program } \\
\text { Studi Teknik Informatika sudah cukup cepat? }\end{array}$ \\
\hline & Apakah Anda setuju bahwa menu-menu pada Sistem \\
\hline$E$ & $\begin{array}{l}\text { Informasi Visitasi Akreditasi Program Studi Teknik } \\
\text { Informatika sudah berjalan dengan baik? }\end{array}$ \\
\hline
\end{tabular}

Penilaian yang diberikan berdasarkan pada indikator penilaian seperti pada Tabel 8 .

\section{Tabel 3. Indikator Penilaian}

\begin{tabular}{lll}
\hline Indikator & & Nilai \\
${$\cline { 1 - 1 }$} }$ & & 2 \\
Kurang Setuju & 3 \\
Cukup Setuju & 4 \\
Setuju & 5 \\
Sangat Setuju & 2 \\
\hline
\end{tabular}

Untuk mengetahui tingkat kepuasan pengguna, digunakan indikator kepuasan pengguna yang ditunjukkan pada Tabel 4.

\section{Tabel 4. Indikator Kepuasan Pengguna}

\begin{tabular}{ll}
\hline Persentase & Keterangan \\
\hline $81 \%-100 \%$ & Sangat Puas \\
$61 \%-80 \%$ & Puas \\
$41 \%-60 \%$ & Cukup Puas \\
$21 \%-40 \%$ & Kurang Puas \\
$0 \%-20 \%$ & Tidak Puas \\
\hline
\end{tabular}

Hasil pengukuran tingkat kepuasan pengguna Sistem Informasi Visitasi Akreditasi Program Studi Teknik Informatika yaitu admin, kaprodi, penilai internal serta dosen yang terlibat dalam proses akreditasi program studi ditunjukkan pada Gambar 14. 


\section{Tingkat Kepuasan Pengguna}

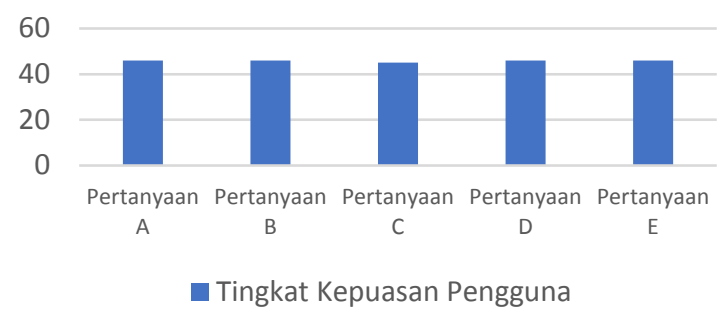

Gambar 14. Grafik Pengukuran tingkat kepuasan pengguna.

Total nilai maksimal indikator penilaian $=275$

Persentase kepuasan pengguna $(\%)$

$=\frac{\text { Total nilai pengguna }}{\text { Total nilai maksimal }} \times 100 \%$

$=\frac{229}{275} \times 100 \%$

$=83.27 \%$

Berdasarkan hasil pengukuran tingkat kepuasan pengguna, dapat diambil kesimpulan bahwa pengguna sangat puas dengan Sistem Informasi Visitasi Akreditasi Program Studi Teknik Informatika dengan persentase kepuasan sebesar $83.27 \%$ yang termasuk pada range $(81 \%$ - $100 \%)$ berdasarkan Tabel 4 .

Hasil pengujian membuktikan bahwa sistem informasi telah mampu memenuhi semua fungsi yang disediakan pada sistem sebelumnya [1-10] untuk pengguna sistem meliputi Kaprodi, penilai internal, tim asesor, dan staf administrasi. Pada sisi yang lain, sistem informasi telah menyediakan fitur inovasi baru berupa rekapitulasi nilai dari asesor internal yang dapat memberikan evaluasi pada program studi sebelum dinilai oleh asesor dari BAN-PT serta data standar yang dinamis sehingga dapat disesuaikan dengan data standar baru bila terjadi perubahan aturan penilaian borang akreditasi.

\section{Kesimpulan}

Sistem Informasi Visitasi Akreditasi Program Studi Teknik Informatika telah berhasil dibuat dengan menggunakan Framework Laravel. Kemudian telah diuji pada tiga browser dengan hasil semua fungsi dapat berjalan dengan baik serta telah dilakukan implementasi dan pengujian kepada 11 responden dan didapatkan hasil presentase sebesar $83.27 \%$ yang berarti bahwa pengguna merasa sangat puas dengan sistem ini.

\section{Referensi}

[1]. S. Suwarto and R. Roestam, "Analisis dan Perancangan Sistem Informasi Administrasi Akreditasi Berbasis Web pada Badan Akreditasi Provinsi Pendidikan Anak Usia Dini dan Pendidikan Non Formal (BAP Paud dan PNF)," J. Manaj. Sist. Inf., vol. 2, no. 3, pp. 661-674, 2017.

[2]. D. M. Informatika, F. Teknik, U. N. Surabaya, and I. G. L. P. E. Prismana, "Rancang Bangun Sistem Perhitungan Penilaian Akreditasi Sekolah / Madrasah Berbasis Web," Inov. J. Ilm. Inov. Teknol. Inf., vol. 1, no. 1, pp. 1-11, 2016.

[3]. N. Saputri, Catur, and Wulan, "Sistem Informasi Akreditasi Prodi (Siakap) Berbasis E- Arsip Untuk Menunjang Persiapan Akreditasi Prodi (Studi Kasus Pada Prodi D3 Universitas Negeri Semarang)," 2015.

[4]. T. S. Sukamto, L. E. Nugroho, and W. W. Winarno, "Desain Sistem Informasi Akreditasi Program Studi Berbasis Website di Indonesia," in Seminar Nasional Aplikasi Teknologi Informasi (SNATi), 2016, pp. 1907 5022.

[5]. E. Putro, "Aplikasi Sistem Penyusunan Borang Akreditasi Program Studi ( Buku III-A )," J. Tek. dan Ilmu Komput., vol. 3, no. 9, pp. 98-107, 2014.

[6].. D. D. Chandra, I. Indrawan, D. I. Ricoida, and N. Rachmat, "Sistem Informasi Dokumentasi Borang Akreditasi Studi Kasus : Program Studi Sistem Informasi Pada STMIK GI MDP,” STMIK GI MDP, 2015.

[7]. A. A. Raditya, K. Kartono, and I. K. Raharjana, "Sistem Dashboard untuk Persiapan Akreditasi Program Studi Sarjana Berdasarkan Standar BAN-PT," J. Sist. Inf., vol. 8, no. 1, pp. 871-882, 2016.

[8]. I. M. Putrama, D. G. H. Divayana, and P. W. A. Suyasa, "Rancang Bangun Sistem Informasi Pengelolaan Data Kemahasiswaan Untuk Akreditasi Program Studi Di FTK Undiksha," in Seminar Nasional Vokasi dan Teknologi (SEMNASVOKTEK), 2016, pp. 194-202.

[9]. S. Nurmiati and H. Munandar, "Sistem Informasi Kegiatan Akademik Untuk Akreditasi Program Studi Berbasis Web Studi Kasus Program Studi Manajemen Sumberdaya Perairan - IPB," J. Sist. Inf., vol. 5, no. 5, pp. 514-523, 2016.

[10]. J. N. Sari and W. Yunanto, "Desain Sistem Informasi Evaluasi Diri Program Studi Teknik Informatika Politeknik Caltex Riau," in SNTIKI III, 2011, pp. 225229. 